Stine Liv Johansen, Institut for Kommunikation og Kultur, Aarhus Universitet, stineliv@cc.au.dk Lone Koefoed Hansen, Institut for Kommunikation og Kultur, Aarhus Universitet, koefoed@cavi.au.dk

\title{
S[k]amtaler Om etnografisk metode og forskerpositioner
}

\begin{abstract}
Researching a phenomenon like the Norwegian TV-series SKAM further complicates the inside-outside notion already debated within ethnographic methods. With SKAM, the reception takes place in a multi-platform and always-on environment: the fan culture(s) happen(s) across several online platforms and the series makes use of a particular understanding of 'liveness' when it updates the story throughout the week, at random times, and on several platforms. This directly influences a researcher's positioning and modes of action. In this paper, we discuss the act of researching SKAM through analysing empirical data from our conversation on Messenger in which we-in the eight months it lasted - acted both as fans or viewers and as researchers aiming to understand SKAM's fandom. In this case of an continuously updating narrative that seems to happen in a parallel universe to our everyday life, what might 'being-there' entail for researchers?, we ask. The methodological perspectives thus discussed here relate to auto-ethnography as well as to media-ethnography, allowing us to discuss how SKAM was a phenomenon that interfered into our professional but definitely also into our private lives.
\end{abstract}

Keywords: SKAM, netnografi, reception, fankultur, forskerpositionering, autoetnografi, tv-serier

Indledning

Being a mobile social media ethnographer does not only involve following the (digital) action, but also getting caught up in it, being carried along the trail and becoming entangled with others... (Postill \& Pink, 2012, s. 10)

Vi har ført en otte måneder lang samtale på Messenger, fra pausen i SKAMs sæson 3 og indtil serien sluttede i juni 2017. Tråden er fyldt med screenshots af andres samtaler på Facebook, diskussioner om forskningsperspektiverne i det, vi oplevede, og beretninger om, hvor(dan) SKAM brød ind i vores dagligdag. Med udgangspunkt i vores oplevelser med at være SKAM-seere og -forskere, vil vi i denne artikel beskrive og diskutere, hvordan en online tilstedeværelse (også som forsker) konstant vikler sig ind $i$ ens liv, når man studerer et internetrelateret fænomen. Som Postill \& Pink påpeger, så er internettet et "messy fieldwork environment that crosses online and offline worlds and is connected and constituted through the ethnographer's narrative." (2012, s. 5)

Vi vil med denne artikel vise, hvordan det så ud i praksis; vi fulgte ikke bare SKAMs narrativ, men skabte også vores eget som empiriske forskere. Vi følte, at vi var nødt til at være "til stede", når det skete, uanset hvor vi var, "in real, experiential ways" (Postill \& Pink, 2012, s. 11). Både fordi det var den oplevelsesstrategi, som andre fans havde (dvs. vi opførte os som fans), og fordi det forskningsmæssigt føltes som en umulig opgave at skulle få det 
til at give mening som et samlet hele på et senere tidspunkt. Det er netop denne artikels emne: Hvordan ser en forskningsproces ud, når man forsker i en fiktiv begivenhed, som foregår lige nu og her, som blander sig ind og ud af ens eget hverdagsliv samt flere forskellige medieplatforme, og som man ikke helt ved hvad er, før man får vendt og drejet den, mens den sker.

\section{Og forskningstiden (og rummet) er sprængt på alle mulige måder gennem vores dialog, der breder sig ind over vores egne tid og rum.}

\section{Jeps. Og pludselig har man officielt en forskningsdiskussion på Messenger of all places!}

Figur 1. Med udgangspunkt i vores samtale på Messenger undersøger vi, hvordan en forskningsproces ser ud, når ens studieobjekt blander sig ind og ud af ens eget hverdagsliv.

\section{Netnografi - altid på, altid med}

The everyday life of the social media ethnographer [...] involves charting out and living through the ethnographic place of the fieldsite, which is a sensorily embodied, rather than 'virtual' experience. (Postill \& Pink, 2012, s. 6)

Strukturen i SKAM, hvor små klip af varierende længde lægges på http://skam.p3.no/ på uforudsigelige tidspunkter i løbet af ugen, lægger op til, at seerne følger løbende med. Dette underst $\varnothing$ tter en følelse af, at serien foregår i et slags parallelt univers i Oslos gader, og det styrker indlevelsen og identifikationen med seriens karakterer. For mange af seriens fans blev netop denne struktur en afgørende faktor i forhold til deres engagement i serien, og de forstærkede den ved at deltage aktivt i dedikerede fangrupper på Facebook, bl.a. KosegruppaDK, SKAM Fri og Ekte 20+ (FogE) og \#SKAMSIRKEL. For andre fans var dette aspekt mindre betydningsfuldt; de så serien mere traditionelt, når den udkom som et samlet afsnit hver fredag aften på NRK (eller hver søndag på DR3). Vores måde at se serien på var helt klart den første, og det er med dette afsæt, at vi diskuterer vores forskerposition. Strukturens indbyggede uforudsigelighed bliver et grundvilkår, som man som forsker er nødt til at lade sig opsluge af, hvis man vil forstå, hvordan et fænomen som SKAM kan få betydning i menneskers liv. Den oplevelse, som fans (og dermed vi) har, bliver formet af mobiltelefonen, både fordi den er adgangsvejen til indholdet (klip og andet indhold, diskussioner i Facebook-grupper, samt vores indbyrdes diskussion på Messenger) og fordi den altid er med os i hverdagslivets $\emptyset$ vrige praksisser.

Nyere, kvalitativ medieforskning tager ofte sit udgangspunkt i en variant af (digital) etnografisk metode, der bygger på klassiske, etnografiske principper, herunder et holistisk perspektiv på det undersøgte felt og en kritisk bevidsthed om den position, hvorfra man som forsker foretager sin unders $\varnothing$ gelse. I mange akademiske undersøgelser krydres dette dog med en positivistisk ambition om at undgå at 'forurene' de data, man 'indsamler', fordi man forestiller sig, at man netop online kan være en usynlig flue på væggen. Etnografiske unders $\varnothing$ gelser, der finder sted online, synes i den sammenhæng taknemmelige, da det ofte er muligt som forsker at agere relativt anonymt som bruger af eksempelvis sociale netværksmedier.

Det er dog ikke nødvendigvis en ambition, man skal stræbe efter, hvis man ønsker at forstå, hvordan det online og det offline liv smelter sammen og er hinandens forudsætninger i hverdagslivets praksisser. Tværtimod er der en pointe i, som forsker, at fors $\emptyset$ ge at omfavne de rodede og uforudsigelige praksisser, som digitale og sociale medier anvendes i. Det handler således ikke om at kunne identificere sociale mediepraksisser som tekst eller for den sags skyld som et afgrænset og definerbart netværk; det handler -- iflg. bl.a. Pink og Postill (2012, s. 1) -- om 
'a critical departure from the dominant paradigms of network and community in internet research', som skal føre til en forskning, hvori 'engaging concepts of routine, movement, and sociality to enable us to understand the practices and places of social media ethnography' (ibid.). I vores arbejde med SKAM som fænomen blev det således en ambition for os at komme så tæt på den indlevede og opslugte oplevelse af brugen som muligt. Vi ville 'være der', både i tid og rum (Frykman \& Gilje, 2003; Hine 2000).

Vores engagement i serien -- og vores indbyrdes diskussioner om den -- medfører, at vores feltarbejde får autoetnografiske toner, eller kan siges at forholde sig til auto-etnografiske pointer. Formålet med vores feltarbejde - og emnet for denne artikel -- er således ikke at opnå en forståelse af, hvordan andre mennesker så og oplevede SKAM, men netop at vise, hvordan vi så og oplevede serien, fordi vi derved får en dybere indsigt i fænomener, som kan være vanskelige at registrere og forstå hos andre end en selv. Vi argumenterer dog for, at denne indsigt fungerer som en vej ind i en $\emptyset$ get forståelse af, hvordan denne form for emergerende mediefænomener føles og fungerer generelt. Det handler således om at anvende autoetnografi som en 'approach to research and writing that seeks to describe and systematically analyze (graphy) personal experience (auto) in order to understand cultural experience (ethno)' (Ellis et.al., 2011, s. 1).

\section{Hvad man taler om, når man forsker i SKAM}

'Antropologen må ind i den verden, der undersøges, og det gøres ved at tage plads i den; det er ikke alle pladser, der er åbne for antropologen (det er det heller ikke for de andre i fællesskabet), men en plads må man have'. (Hastrup, 2003, s. 10)

Vores undersøgelse af SKAM begyndte med, at vi som kolleger udvekslede små begejstrede udbrud og kommentarer i relation til de klip, vi så. Herfra fulgte en erkendelse af, at vi havde bevæget os ind i et felt, hvor vi måtte reflektere over vores position som forskere -- eller rettere som forskerteam. Vi måtte altså finde en plads i den kultur, vi ville undersøge, hvorfra vi var i stand til at registrere og erkende -- og dermed forstå -- dens præmisser og perspektiver.

Vores ærinde var således at forstå den særlige receptionsstrategi, der for mange af seriens fans blev omdrejningspunktet i den periode, hvor serien blev sendt. Vores plads var -- ligesom andre fans' -- i vores konkrete hverdagsliv og i de online fællesskaber, der opstod, og som hurtigt voksede til et sjældent set omfang. På den ene side foretog vi online feltstudier som deltagende observatører i fangrupperne, men vi satte os også for at mærke på vores egen krop, hvad det vil sige at være optaget af et fænomen, der griber ind i ens hverdag via smartphonen og dens løbende notifikationer om nye klip, nye kommentarer og nye samtaler. Vi så altså SKAM-indholdet, når det blev lagt ud på http://skam.p3.no/ eller på andre platforme, såsom Instagram og (i S4) YouTube -- stort set uanset hvor vi befandt os. Vi lod os rive med i fornemmelsen af, at man er lukket ude af fællesskabet, hvis man ikke hele tiden følger med og bidrager til diskussionerne. Dermed registrerede vi, hvordan seriens struktur greb ind i vores hverdag på en særlig måde. Vi oplevede den stress, der opstod, når der kom nye klip, og samtidig skulle vi sørge for ikke blot at se, men også dokumentere dem, og måtte således erkende at 'fieldwork often shifts between periods of relative calm and periods of intense activity, even turbulence' (Pink \& Postill, 2012, s. 9).

Vores positionering som 'fans' ses især i de umiddelbare reaktioner på aktuelle klip og/eller andre former for indhold. Disse reaktioner er oftest affektive og bliver ikke nødvendigvis fulgt op af yderligere analyser. Et eksempel på dette ses herunder i figur 2 fra en af de sidste uger af sæson 4, hvor konflikterne mellem Sana og veninderne endelig ser ud til at løse sig, og pigegruppen Los Losers opstår med stor forløsning. 


\section{Fuldstændig.}

\section{Det krævede lige et nyt coverbillede}

\section{\#loslosers er fandeme også et godt hashtag}

\section{jeg vil have en $\mathrm{t}$-shirt med det hashtag.}

Figur 2. I SKAM opstår Los Losers under stor jubel, og vi ser her et eksempel på, hvordan vores forskningsposition blander sig med fankulturen i affektive udbrud, analyser samt konkrete, medierede handlinger.

Vores kontinuerlige samtaler handlede meget ofte om, hvor vi var, og hvordan vi kunne se (eller havde praktiske vanskeligheder med at kunne se) nye klip. Et par gange så vi et klip sammen, hvis vi tilfældigvis var fysisk til stede det samme sted, men som hovedregel så vi klip og andet indhold hver for sig (mere eller mindre synkront) og var i kontakt med hinanden via Messenger. Samtidig tog vi screenshots af væsentlige tråde og hændelser i kommentarfeltet på http://skam.p3.no/ og i de forskellige Facebookgrupper, vi fulgte. Ofte var det med det formål at dokumentere, hvordan en diskussion udviklede sig over tid; vi tog fx screenshots af potentielt interessante kommentarer, eller dokumenterede aktiviteten med screenshots umiddelbart efter et klip var offentliggjort, 10 minutter og en halv time efter, alt efter intensiteten i diskussionen. Hvis den ene af os var forhindret i at se et klip eller i at tage screenshots, prøvede vi at sørge for, at den anden gjorde det, se figur 3. 
Der er nyt klip. Åh altså. Der er stadig noget $\emptyset$ uden bro i spil.

Og jeg kan ikke følge med i KosegruppaDK de næste to timer, FYl.

Figur 3. Hverdagen kommer nogle gange i vejen for forskningen, men selv midt i de umiddelbare reaktioner på et nyt SKAM-klip, titter forskeren frem, når empiri-opsamlingen skal sikres.

Vores efterhånden meget fyldige samtaletråd på Messenger blev på den måde en form for fælles notesblok, hvor vi både gav udtryk for vores umiddelbare reaktioner og noterede analytiske pointer, som vi kunne vende tilbage til, ligesom vi her postede særligt interessante screenshots eller billeder af den situation, vi var i, mens vi fx så et klip. I andre tilfælde trak vi erfaringer fra vores eget liv ind i vores fortolkninger. Det kan være, når vi huskede tilbage på vores egen teenagetid, eller når Stine -- som mor til to teenagere -- relaterede fiktionen til hændelser i hendes eget eller hendes børns liv. Da klippet med 'hotel-scenen' i sæson 3 (hvor det under stort drama går op for Isak, at Even er bipolar) udkom en sen fredag aften i december 2016, sad Stine derhjemme, mens hendes børn og deres venner holdt fest i huset (se figur 4). Sammenhængen mellem det fiktive teenagedrama og det drama, der fandt sted på etagen nedenunder, føltes i det øjeblik meget fremtrædende. Det var ligeledes den samme aften, at Stine gik i 'mor-mode' og fik en umiddelbar trang til at redde stakkels Isak fra alt det kaos, han stod midt i, mens Lone gættede på, hvad næste træk i handlingen mon bliver: 
Så fik vi afklaring - har du set det?

KosegruppaDK havde ret $\mathrm{i}$ alt.

Håber på en sms fra Isak til Jonas kl 01.02

( $\mathrm{Ja}$, jeg er grebet.)

Og jeg går helt i mor-mode. Har bare lyst til at køre ind og hente ham. Stakkels Isak

Netop.

Jeg vil ringe til Jonas.

Jeg tror altså de har brug for en voksen her. Isaks

far, $\mathrm{fx}$.

Figur 4. I sæson 3s dramatiske højdepunkt sad Stine derhjemme, mens hendes børn og deres venner holdt fest i huset - for et $\varnothing$ jeblik føltes SKAMs narrativ ekstra nærværende.

Ofte var vores samtaler mere udfoldede og antog form af egentlig analyse. Dette kunne være knyttet til teksten og til den fortællemæssige fremdrift, til de tekniske og dramaturgiske virkemidler (herunder sammenhængen mellem de forskellige medieplatforme) eller til de analyser, der i stor stil udspillede sig i fangrupperne på Facebook.

Der er ingen tvivl om, at vi -- bevidst eller ubevidst -- var gensidigt påvirkede af analyserne i grupperne, hvor fans udviste stor analytisk kompetence. Dette ses bl.a. i vores ordvalg og sprogbrug og i de temaer, som vi kredsede om. For eksempel havde vi i december og især i begyndelsen af januar en længere diskussion om begrebet fokalisering (at fortællingens vinkling er bundet til hovedpersonens perspektiv). I nedenstående eksempel (figur 5) ser vi norske ord (lekser, greier), fanreaktion på klippet (skrækkelig scene), en serie-intern komparativ analyse, personlige oplevelser ift seriens narrativ (genkender godt) samt indledning på en faglig samtale om fokalisering og sammenhængen til tilsvarende begreber: 
Ja, den er skrækkelig. Jeg har lige set den igen i dag (må jo gøre lekser). Synes Jonas disses mere end han har fortjent. Han har en masse greier, han skal holde styr på, og vil gerne virke cool over for Elias, men han er $100 \mathrm{p}$ klar over, at Eva er ked af det. Kan bare ikke finde ud af at handle på det

Og Evas mor får også hug. Jeg synes det er synd for hende. Genkender alt for godt, at når man selv endelig er hjemme efter en presset periode, så har teens ikke tid til at se en

\section{Vi kan jo starte en tråd hvor folk får mindre tæsk. (-) Derudover er det interessant at gense S1 når man har oplevet det med den farvede fortæller senere: altså at alt her ses skarpt med Evas briller.}

Fokalisering, er det det, I mediefolk kalder det, der i litteraturvidenskab mest hedder upålidelig fortæller?

Figur 5. De norske ord "lekser" og "greier" indgår lige så gnidningsfrit i samtalen som de akademisk-faglige diskussioner om begreber og fortællegreb.

Samtalen fortsætter med links, definitioner og yderligere udfoldning af begrebet og dets anvendelse. Som sådan fungerede Messenger som et backstage-rum, hvori vi kunne reflektere og klæde os på til at deltage i de offentlige diskussioner. På samme måde diskuterede vi selve grupperne og den måde, de fungerede på, og hvordan de adskilte sig fra hinanden. Som for eksempel i den samtale fra 26. april 2017, som er gengivet i figur 6 : 
Ja, de er helt vilde! Og det fungerer bedre med de samlede tråde.

\author{
KosegruppaDK er endnu ved at diskutere om det \\ er ok med det teaterstykke, og om skuespillerne \\ ligner godt nok
}

Figur 6. Back-stage talk om de fangrupper, som vi studerede.

Til vores sammenligning mellem FogE og Kosegruppa DK hører også, at Kosegruppa DK efterhånden nåede op på 40.000 medlemmer, mens FogE stoppede på nogle tusinde, hvoraf størstedelen var meget aktive deltagere $\mathrm{i}$ diskussionen.

Ud over de meget serie-bundne diskussioner, havde vi også en løbende reflektorisk diskussion om, hvad det egentlig er, vi undersøger og hvilke mulige forskningsperspektiver, der ligger i det materiale, vi havde samlet sammen efterhånden. Igen er der tale om en samtale, der finder sted i det lukkede rum, som vores Messengersamtale er, og som derved illustrerer den etnografiske balancering mellem involvering og distance i forhold til den empiriske felt. Det er gennem disse samtaler, der løbende udvikler sig, at vi afprøver analytiske argumenter, og efterhånden når frem til en form for afgrænsning af det mest interessante for os, herunder vores egen rolle, som i nærværende artikel.

Endelig indeholder vores samtale en lang række elementer, der ikke direkte relaterer sig til SKAM. Vi diskuterer for eksempel andre ting, vi har set eller læst i medierne, fortæller om og diskuterer private og arbejdsmæssige ting, og har en del samtaler af praktisk og teknisk karakter. Vi vil ikke gå mere i dybden med de enkelte eksempler på disse typer af indhold, men blot konstatere, at den diversitet, der er i vores samtale, i sig selv understreger, hvordan vores forskningsproces blev en 'always on - always in'-oplevelse for os. 


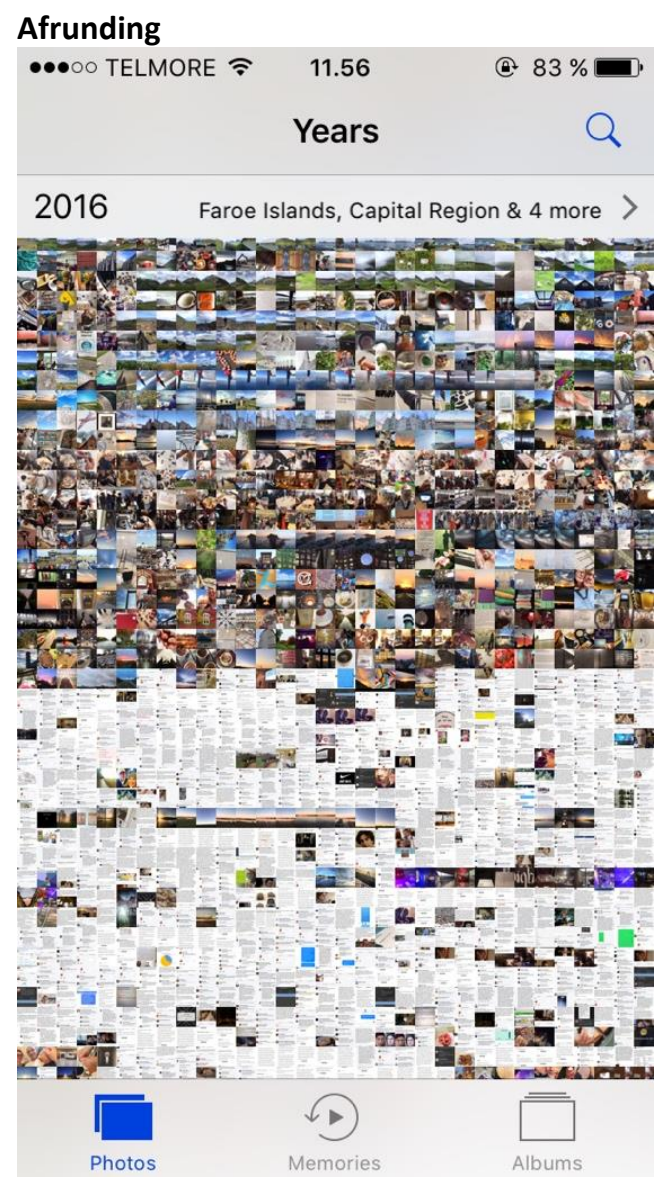

Figur 7. Hundredevis af screenshots sætter deres tydelige præg på Lones telefons fotoalbum i 2016, hvor det er tydeligt at se, hvornår Lone begyndte at forske i SKAM-online-grupperne.

Vi har i denne artikel unders $\varnothing \mathrm{gt}$, hvordan man kan forstå forskerpositioneringer i og omkring emergerende, online fænomener, og hvordan forskning finder sted, når man arbejder med en kulturel og æstetisk hændelse, der som SKAM breder sig over tid, rum og sociale kontekster. Vi var selv ivrige seere, og samtidig var vores reception præget af, at vi er forskere i medier og mobile teknologier, dvs havde en særlig interesse for de forhold, som teknologien og medierne sætter for både serie og reception. Empirisk data er ikke tidsligt neutral, og en vigtig del af den forskningsmæssige bearbejdning bliver at følge med -- hvilket vi fx helt tydeligt kan se på vores mobilers fotoalbums, hvor sidste del af 2016 er fyldt helt op med screenshots fra interessante øjeblikke i diskussionerne i facebookgrupperne (se figur 7). Her fanger vi ikke bare et øjeblik med det formål at databehandle det senere, men markerer gennem screenshottet en forskningshændelse, hvor vi har set noget interessant, som oven i købet kan deles med kollegaen med det samme.

Denne forskningsproces har udfoldet sig, hvor vi tilfældigvis stod, da der skete nyt i SKAM, hvad enten vi var i et tog en sen aften, under en koncert i regnvejr på Northside, i køen i Brugsen, på toilettet til en konference, i de sidste minutter inden undervisning, til julefrokost, på Folkemødet, på kontoret, hjemme i lænestolen, under madlavning, på en togperron i New York, i en bus på vej til Tyskland, siddende i en vindueskarm på Als, i en lufthavn i Barcelona eller gik på Kastellet i København med en soldat i hælene, fordi anlægget skulle lukkes af for natten.

Som Postill og Pink beskriver i vores indledningscitat, så foregår denne type af forskning også ud fra en præmis om, at man skal lade sig blive "caught up in it, being carried along the trail and becoming entangled". I dette tilfælde beskriver citatet både den empiriske forskers og den ivrige fans oplevelse af en serie som SKAM. 
Oplevelsen formes netop ikke kun af narrativet og produktionen selv, men også af, at receptionsprocessen er med til at skabe forventninger til seriens videre forløb, hvad enten det handler om at bekymre sig om seriens plot, eller om receptionens og forskningsprocessens vilkår.

Soldaten på Kastellet satte i øvrigt smilende farten ned, da Lone stakåndet sagde, at hun var lidt optaget af det dér klip, så hun kunne altså ikke gå så hurtigt.

\section{Referencer}

Ellis, C, Adams, T.E. \& Bochner, A.P. (2011). Autoethnography: An Overview. Forum: Qualitative Social Research, 12(1)

Frykman, J. \& Gilje, N. (2003). Being There: New Perspectives on Phenomenology and the Analysis of Culture. Lund: Nordic Academic Press

Hastrup, K. (2003). Ind i Verden. En grundbog i antropologisk metode. København: Hans Reitzels Forlag

Hine, C. (2000). Virtual Ethnography. London: Sage

Postill, J. \& Pink, S. (2012). Social media ethnography: the digital researcher in a messy web. Media

International Australia, 145, 123-134. 